\title{
The Informal Economy as a Site of Liquidity: Pakistan's Land Market
}

\section{Antonia C. Settle}

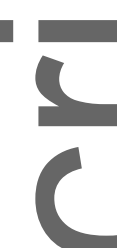

$\infty$

ABSTRACT

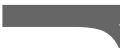

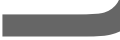

Based on extensive fieldwork, this article examines new informality in Pakistan's land market by which vacant plots of land are transacted informally between market actors in rapidly reversed short-term holdings. The analysis pivots around the changing economic environment in Pakistan with the shift from heavy regulation of money and controlled pricing, to the liberalization of money and markets. The author explores how liquidity is taken up as a microeconomic strategy to protect against new financial risk in this environment, and how this is played out as a preference for informal transactions. These practices inform a case study that contributes to the established literature on the links between globalization and the informal economy by articulating a driver of growing informal transactions that is novel to the literature.

This research has benefited from the input of Dick Bryan and Maqsood Ahmad Jan. Comments from editors and reviewers have been invaluable.

This is the author manuscript accepted for publication and has undergone full peer review but has not been through the copyediting, typesetting, pagination and proofreading process, which may lead to differences between this version and the Version of Record. Please cite this article as doi: 10.1111/dech.12425.

This article is protected by copyright. All rights reserved. 


\section{Introduction}

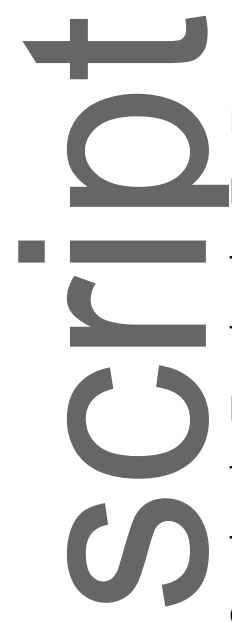

Drawing out the substantive meaning of the globalization of markets from the sticky web of more localized change represents a complex challenge in a world of rapid and unprecedented economic transformation. Within this vast research question, the dynamics of formality and informality, amidst the shifting regulatory structures of a globalizing world, offers an important field of research at a point where sociology, politics and economics meet. With economic development failing to achieve the gradual formalization of markets proposed by early theory, a literature has developed around the issue of how globalization interacts with informal market activity. This literature casts the growth of informal markets as a response to globalization based on exclusion from formal sectors (Coletto, 2010; Meagher, 2010), and in the context of social networks (Meagher, 2005; Portes, 1994) and traditional ties of solidarity and obligation (Hillenkamp et al., 2013). By understanding informality as a question of social networks, the 'dry economics' of flows and prices characteristic of earlier literature has been superseded by an emphasis on the sociality of informal markets (Meagher, 2010: xi).

This article, by contrast, highlights a salient shift into undocumented markets in Pakistan that draws less on social networks than on the greater liquidity that can be facilitated by informal transactions. Specifically, the article examines the informal land market. This does not pertain to the informal settlements familiar to the literature (for example, Birch et al., 2016; Hasan et al., 2015; Marx, 2009; Shatkin, 2004) but to markets for the undocumented exchange of otherwise formal plots of land. This article sets out a distinctly monetary context that rests heavily on the economic implications of rapidly changing flows and prices. Here market actors choose to bypass both the costs associated with the formal documentation of land transfers and the protection of the state in designating property rights, in exchange for significantly enhanced liquidity in the land asset.

The analysis pivots around the changing economic environment in Pakistan, with the shift from heavy regulation of money and controlled pricing, to the liberalization of money and markets and accompanying monetary instability. The study draws on fieldwork interviews undertaken in Pakistan by the author, which apply a methodology based on key insights from finance theory to explore the experience of financial risk in the post-liberalization environment. Specifically, the study

This article is protected by copyright. All rights reserved. 
explores the possibility that evidence of growing informality in Pakistan's land market reflects demand for short-term store-of-value assets amidst volatile monetary conditions. Cast in this light, the appeal of informality lies in its liquidity insofar as liquidity facilitates transactional access to savings. As such, the study proposes that informal holdings in the land market may be functioning as a kind of risk management strategy, or hedge, in the face of persistent economic and financial instability under open markets. The identification of such practices in the field informs a case study that contributes to the established literature on the links between globalization and the informal economy by articulating a novel driver of growing informal transactions. At issue are risk management strategies that respond to instability in the monetary environment, suggesting that the significant increase in informally traded land in Pakistan over recent years may be driven by financial imperatives like diversification and liquidity in the face of new monetary risk.

The article first discusses the link between global financial change and increasing monetary volatility. This section sketches out how unstable monetary indicators in the post-Bretton Woods environment can interact with open markets to intensify volatility in key macroeconomic indicators and ratios found in a set of empirical articles on Pakistan (Choudhary and Pasha, 2013; Hussein et al., 2011; Lopez-Calix et al., 2011; Rashid and Husain, 2010). This instability is constitutive of the unstable monetary context in which the study identifies new risk management practices, which include informal land transactions. The second section discusses fieldwork findings that posit risk management strategies undertaken through techniques of diversification and liquidity enhancement amongst household portfolios of everyday liabilities and assets. The third section explores the role of informality in what are perceived to be a subset of risk management strategies pertaining to the land market in Pakistan; this section explores the possibility that new demand for informally transacted land is structurally linked to prevalent monetary conditions. The final section discusses the existing literature on informal markets, contrasting the characterization of the informal market as a site of liquidity with more established themes in the literature such as trust, social networks and exclusion in a globalizing world.

This article is protected by copyright. All rights reserved. 


\section{Value Instability and Globalization}

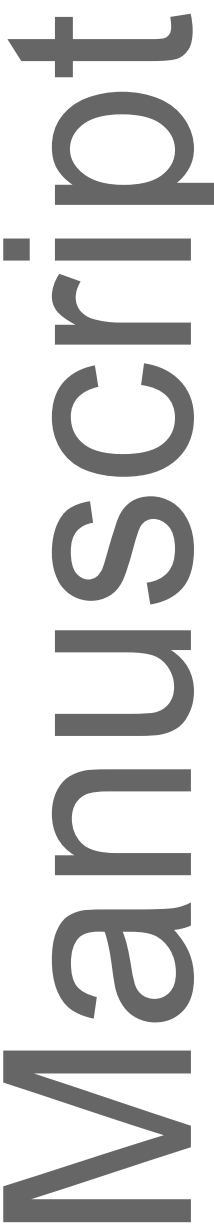

Based on long-run statistical analysis of Pakistan's key economic indicators, senior researchers from the State Bank of Pakistan (SBP), Ali Choudhary and Farooq Pasha, find that generalized instability in Pakistan has increasingly become an economic norm over the last 30 years: 'The only "stable" stylized fact [for Pakistan's economy] is the instability that exists in key economic ratios and relationships' (Choudhary and Pasha, 2013: 34). Moreover, 'what is of more concern', they conclude, 'is that this instability has increased over the last decade' (ibid.: 34-35). These findings of greater volatility in key macroeconomic ratios and relationships, such as those between output and investment, output and consumption, and output and the external sector, support other statistical findings of heightened volatility. World Bank research on stylized facts in the Pakistani economy highlights increasing volatility in Pakistan's GDP in the decade 2000-2010 (Lopez-Calix et al., 2011). SBP research identifies this as a 'four-fold increase in Pakistan's real GDP volatility over the past three decades [which] coincided with the emergence of a deregulated financial sector since the 1980s' (Hussein et al., 2011: 2). Moreover, Rashid and Husain (2010) find intensifying inflationary pressure and exchange rate instability linked to growing capital inflows over the same period. In this environment, it is unsurprising that recent research at the SBP finds very little price rigidity and weak real wage rigidity (Ahmed et al., 2013; Choudhary et al., 2016).

These studies make empirical contributions towards understanding how the Pakistani economy has changed through the relatively rapid years of transition to open markets. From a centrally controlled economy characterized by import-substitution and administered pricing until the 1990s, the Pakistani economy has transitioned to an open economy with money and markets that have been largely liberalized from state control since the mid-2000s (Meenai and Ansari, 2004; ul Haque, 2011; Zaidi, 2015). With this economic shift, the rupee has been liberalized from administered interest rates, centralized credit allocations and a fixed exchange rate, at the same time that foreign currency holdings have been legalized, the current account has been liberalized and price controls have been removed.

Importantly, these changes have occurred in Pakistan in a context of significant long-run change in the global economy. The collapse of the Bretton Woods system of fixed exchange rates in

This article is protected by copyright. All rights reserved. 
the early 1970 s is pivotal because the new degree of monetary volatility that accompanied floating rates established fundamentally new financial conditions. This order of volatility significantly exceeded that predicted by academic proponents of floating rates prior to the final closure of the gold window (Eichengreen, 2008: 138). With these changes came wide-ranging liberalization of trade, investment and finance (Helleiner, 1994), first in the advanced economies and later amongst emerging and less-developed economies (Ito and Chinn, 2017). The incredible growth of turnover in foreign exchange markets combined with the huge growth in global liquidity presents a world of finance unimaginable to policy makers in the Bretton Woods years. ${ }^{1}$

In Pakistan, the rupee was floated in 2000. Alongside the floating value of the rupee in terms of other currencies, the purchasing power of the rupee in terms of everyday prices in the economy has become much more variable since liberalization. Historically a low-inflation economy (Hamid et al., 1990: 17; Hasan et al., 1995; Zaidi, 2005: 293), inflation has become a reoccurring issue under open markets. This is in large part driven by the economy's new and largely unmediated exposure to global commodity prices, exacerbated by pro-cyclical exchange rate shifts and speculative pressure (Abbas et al., 2015; Hanif et al., 2016; Khan, 2015; Khan and Ahmed, 2014). Yet as the statistical work on Pakistan cited above suggests, volatility in the post-Bretton Woods era runs deeper than instability in narrow monetary indicators. Drawing on the conceptualization of fundamental volatility rooted in the regime of monetary and financial governance in the work of Dick Bryan and Michael Rafferty (2006), the proposition carried throughout this article is that unstable money poses a fundamental problem to the economy.

Pakistan's own 'homegrown' 2008 crisis (ul Haque, 2010: 1) demonstrates how liberalized money interacts with the global exposure of domestic markets and generates instability that reverberates across the economy. When global commodity prices spiked in 2008 , the rupee faced downward pressure as the import bill surged (SBP, 2008: 147). As foreign exchange reserves rapidly depleted, the downward pressure generated by the reversing terms of trade put acute speculative

${ }^{1}$ Although world GDP doubled between 1995 and 2014, turnover in foreign exchange markets increased almost fivefold over the same period. Reflecting the trajectory of foreign exchange turnover, global liquidity had remained fairly stable until the mid-1990s, after which point it rose sharply (Brana et al., 2012).

This article is protected by copyright. All rights reserved. 
pressure on the rupee (ibid.: 49), exacerbating the high costs of imported commodities in rupee terms. At the same time, the jump in commodity prices spread throughout the economy, producing a sharp increase in inflation (SBP, 2009: 75). These effects severely degraded the usefulness of the rupee as a store-of-value.

Similar bouts of instability recurred throughout the following years, featuring as a constant threat of crisis amidst persistent volatility in monetary indicators. Electricity shortages, unpredictable price effects in the external sector, debt servicing and deterioration in the financial account were all major themes for the SBP in its efforts to manage the rupee under open markets. ${ }^{2}$ As eminent Pakistani economist Akbar Zaidi (2015: 544) notes, 'all key [economic] statistics deteriorated in the 2008-13 period'. Volatile monetary indicators persisted, with shocks to key food prices and exchange rate volatility persisting through 2014 and 2015 despite improving macroeconomic indicators. ${ }^{3}$ Yet Zaidi argues that hidden behind these alarming macroeconomic indicators is not so much a crisis, but rather a resilience rooted in the undocumented economy that has kept crisis at bay. For Zaidi, the informal economy has sustained wages and consumption in the everyday economy in spite of the decidedly downcast statistics generated by formal production and trade.

By contrast, the proposition proffered in this study is that while 'the oft-repeated cries of "collapse and crisis" now sound terribly repetitive and boring' (ibid.), these cries indicate a sustained and fundamental uncertainty linked to the liberalization of money and markets in Pakistan. Indeed the interaction between the rupee's value in exchange rate terms, the external account and the reliability of the rupee as the funding currency of everyday subsistence items has been a major concern both at the level of the SBP and at the level of the street over the last decade. That is, with

${ }^{2}$ These themes recur throughout SBP Annual Reports over these years. See for example the 'Domestic and External Debt' chapter from the FY 2011 Annual Report; the 'Balance of Payments' chapter from the FY 2012 Annual Report; and the 'Balance of Payments' chapter from the FY 2014 Annual Report. These are all available at www.sbp.org.pk.

${ }^{3}$ Shocks to key food prices can be observed in the Sensitive Price Index, which tracks the prices of essential items; this has been available on a weekly basis since January 2013 on the Pakistan Bureau of Statistics website: www.pbs.gov.pk/content/price-statistics. Exchange rate volatility can be observed in the SBP's economic data at www.sbp.org.pk/ecodata/index2.asp.

This article is protected by copyright. All rights reserved. 
the value of the rupee oscillating on markets, the price of everyday goods (which themselves are exposed to price shocks in global markets) has become much more volatile. In these conditions, the affordability of next week's basket of basic consumer goods is complicated by interacting shocks to individual prices in the basket and shocks to the unit of account of that basket. Quantitative work shows that prices and wages in Pakistan are much less sticky than in the developed economies (Ahmed et al., 2013; Choudhary et al., 2016), while in developing countries in general, exchange rate volatility feeds more quickly into domestic prices and inflation is more severe, more persistent and more frequent than inflation in the advanced economies (Agenor and Montiel, 2008; Anand and Cashin, 2016; Walsh, 2011). These conditions undermine the usefulness of the rupee as a store-ofvalue for the future purchase of everyday goods.

More than a problem of nominal proportions only, volatility in monetary indicators feeds into a more broad-based uncertainty that offers some explanation of findings of intensified volatility in economic indicators since liberalization (Choudhary and Pasha, 2013; Hussein et al., 2011; LopezCalix et al., 2011; Rashid and Husain, 2010). This article shows how, amidst this volatility, we find alternative iterations of informality, the salience of which lies not so much in the capacity of informal markets to function as a social safety net but more in the capacity of informal markets to function as a site of liquidity in a context of financial uncertainty.

\section{Volatility and the Liquidity Imperative}

Finance theory tells us that liquidity and diversification are key principles which are employed by investors in the face of uncertainty. From Keynes's liquidity preference theory (Keynes, 1936) through 1950s portfolio theory (Markovitz, 1959) and capital asset pricing models (Black and Scholes, 1973), these principles remain core risk management strategies for insulating portfolios against the risk of making a loss in the event of a price shock to the value of an asset or liability. Even at the household level, a negative shock to asset values or a positive shock to liability values tips a

This article is protected by copyright. All rights reserved. 
balance sheet, imposing new financial constraint. Thus, be it a reduction in the purchasing power of money held in a bank account (an asset), an increase in the cost of electricity (a liability), or an oscillation in the wheat price (often an asset for rural households but a liability for urban households), the reliability with which future costs can be met from a set flow of incoming resources becomes more precarious as volatility in prices across an economy increases.

By diversifying the forms of asset holdings, the entire portfolio will not be denigrated in the case of a price shock in one class of assets. Diversification seeks a spread of assets, the prices of which will cycle differently. By holding liquid assets, moreover, positions can be quickly reversed if a price shock arises. As one investment firm explains, 'in a volatile market, liquidity is crucial. If you owned Enron stock in 2001 and suspected that it was in trouble, you needed only call your stockbroker and tell him to dump it. Two minutes later, you're out. No need to ride it from $\$ 100$ down to five cents' (Players Capital Group, 2014). Alternatively, a portfolio of liquid assets promises that assets can rapidly be summoned for unexpected market opportunities, which themselves are more likely to arise in volatile conditions.

The key argument of this article is that these dynamics play a role in what appears to be a significant increase in informally traded land in Pakistan since 2008. In order to make this argument, this section first discusses findings related to liquidity and diversification in wider fieldwork interviews in Pakistan. This discussion builds on the description of volatility in Pakistan presented above, by describing what are agued to be microeconomic responses to volatility linked to the liberalization of money and markets in Pakistan. More specifically, it undertakes a very brief discussion of how core principles of risk management under uncertainty can be identified in changing financial strategies undertaken by ordinary working people in Pakistan - such as small and medium traders in the bazaar, farmers and agricultural workers - as well as wealthier traders and business people. The undocumented trade in plots is identified as a subset of these microeconomic strategies and discussed in the following section.

Fieldwork undertaken by the author in 2014 and 2016 sought to explore if people are undertaking new money strategies to combat new risk in the context of instability in the post-

This article is protected by copyright. All rights reserved. 
liberalization environment. ${ }^{4}$ New money strategies were explored in terms of diversification and liquidity enhancement across the portfolio of everyday assets and liabilities and especially in relation to strategies that hedge new risk in the rupee specifically. The fieldwork methodology did not attempt a representative survey of which respondent groups use which instruments to what degree. Neither did it seek to develop an ethnographic description of the subjective and culturally mediated experience of financial risk. Rather, this study was designed to explore how an array of new money strategies identified in the field disrupt assumptions about everyday money use and thereby demonstrate significant features of the local monetary environment. This in turn generated findings about informality, which are discussed in the next section. Although the survey undertaken for this study is necessarily small and the conclusions modest, the findings are suggestive of wider meaning.

The field interviews were semi-structured and were centred on open-ended questions in an in-depth interview format carried out with small samples of everyday economic actors. The interviews focused on how people manage liquidity within their portfolios of everyday assets and liabilities and sought to decipher if shifts towards greater liquidity and diversification could be detected. Here portfolios were interpreted in terms of wages, housing costs, staple food commodities and consumer durables, rather than strictly formal sector financial instruments. This boiled down to questions around what kinds of store-of-value instruments were relied on by the interviewee, both for short- and medium-term holdings; and whether these instruments were the same as those used in the pre-liberalization era.

For this kind of information, individual interviews are crucial. Individual interviews grant access to information about how those individuals combine different money strategies that would be lost from a survey format involving closed-ended questions. Moreover, the cultivation of rapport through the face to face engagement of in-depth interviews provides a more fruitful context for the

${ }^{4}$ For the purposes of this study, the post-liberalization period is considered to be after 2007. Although liberalization had begun in earnest in the 1990s, it was not until 2008 that the IMF considered the process to be 'virtually complete' (IMF in ul Haque, 2011: 99). Prior to 2008, moreover, the economy was buffered by extraordinary inflows related to the so-called War on Terror as well as the boom in global markets and sale of former state-owned assets on international markets. As such, the impact of liberalization on the rupee was in some ways masked. With the global boom over and heavy US support winding down after 2008, post-liberalization conditions normalized.

This article is protected by copyright. All rights reserved. 
discussion of personal financial matters (Taylor and Lynch, 2016). This approach allowed the study to navigate around sensitivities that complicate field work, namely sensitivities in terms of the taboo nature of the subject of the enquiry, ${ }^{5}$ the cultural contrast between researcher and field informant, and security issues relating to law and order in the field.

\section{Primary interviews were undertaken with individuals who were selected so as to loosely} reflect different geographical regions and ethnic groups and to include representatives from key economic groupings. 'Snowballing' contacts led to the over-representation of some groups and underrepresentation of others. However, the role of the fieldwork was to open up space to question assumptions about everyday monetary conditions rather than unambiguously prove certain findings.

This approach accommodates an uneven sample and the unpredictable nature of field research on such sensitive domains as personal monetary practices.

Primary interviews were undertaken with 15 traders in bazaars in Peshawar, Charsadda, Hyderabad, Karachi and Quetta; five agricultural workers near Khanewal and Rajanpur; one fertilizer dealer in Charsadda; two low-income salaried workers near Khanewal and in Karachi; five money changers and a gold dealer in Lahore, Hyderabad and Peshawar; one large agricultural landowner in Sindh; three commercial bankers in Peshawar and Karachi; and eight people involved in the land market (dealers, developers and planners) in Charsadda, Peshawar, Islamabad, Rawalpindi and Zhob. The interviews also included five customers in the land market, in Karachi, Peshawar, Islamabad, Quetta and rural Sindh. Rural representatives are present in each category except money changers and commercial bankers. The majority of interviewees were male, but three of the six low-income rural interviewees were female. The interviews spanned the country and included each province, with the exception of Gilgit-Baltistan. Interviews were undertaken in Urdu, Sindhi, Seraiki, Punjabi, Pashto and English, with the support of a translator where required.

In order to strengthen the analysis of the primary field interviews and collect further data on the broader context of monetary liberalization in Pakistan, a secondary set of interviews with key

${ }^{5}$ Specifically, Islamic thought frowns upon speculation in favour of productive investment (Kuran, 1986: 136). This casts a shadow over active strategies that respond to nominal instability in money, such as inflation and exchange rate depreciation, because of the connotations of speculation that they entail. Accordingly, the interview questions were designed to avoid direct questions about individuals' responses to monetary instability.

This article is protected by copyright. All rights reserved. 
stakeholders was undertaken. These interviews were with senior SBP officials, policy makers and academics. ${ }^{6}$ These interviews helped to substantiate the findings and to build a richer picture of the policy landscape.

The crux of the fieldwork findings was that active strategies were indeed being undertaken across all groups of interviewees in response to the shift in monetary and economic conditions towards greater volatility. These strategies minimize exposure to the rupee and diversify everyday portfolios with liquid non-rupee instruments. As discussed in greater detail elsewhere (Settle, 2016, 2017), these fieldwork findings were 'triangulated' with other primary and secondary sources to explore what are interpreted as shifts in everyday risk management strategies occurring beyond standard statistics - that is, primarily amongst subsistence goods and in undocumented transactions. Examples emerging from the research of new strategies that hedge new rupee-related risk include a shift out of cash as a store-of-value instrument by rural agricultural workers and lowincome salaried workers. Cash had been found to be the predominant savings instrument at the village level in detailed fieldwork undertaken by Shahina Waheed in the 1990s (Waheed, 1996). However, in interviews undertaken for this research in comparable villages, interviewees reported unanimously that they, like others in their communities, no longer held cash in the home. Although they each reported older cash-storing strategies, such as in brickwork or sewn into linen, respondents now reported a preference for holding cattle or wheat to store value over time. ${ }^{7}$

${ }^{6}$ Key stakeholder interviews included those with Ali Choudhary, Director of Research at the SBP, Karachi, 10 June 2013 and 20 May 2016; Shahid Kardar, former Governor of the SBP, Lahore, 17 June 2013; Mushtaq Khan, former Chief Economist at the SBP, Karachi, 30 August 2013 and 12 May 2016; Hanif Akhai, former Foreign Exchange Advisor at the SBP, Karachi, 20 May 2016; Mushtaq Gaadi, Professor of Anthropology at Quaid-i-Azam University, and expert on agriculture in the Indus basin, 20 June 2013 and 23 April 2014; Abdul Salam, former head of Agricultural Prices Commission, presently Professor of Economics at Punjab University, Islamabad, 13 May 2016; Stephen Davies, Senior Research Fellow at International Food Policy Research Institute, Islamabad, 17 June 2016; and Mubarak Ali, member of the Food Security and Climate Change division of the Government of Pakistan's Planning Commission, Islamabad, 18 June 2016.

${ }^{7}$ These interviews were taken in a village near Khanewal and a village near Rajanpur with members of low-income households through local translation from Punjabi and Saraiki, 24 April 2014 and 27 April 2016. These interviews were with four male farmers, two female farmers and one female

This article is protected by copyright. All rights reserved. 
Extensive fieldwork undertaken by the Social Sciences Collective, Karachi (Balagamwala and Gazdar, 2014; Gazdar and Mallah, 2013), similarly points to the popularity of holding cattle and of stockpiling wheat amongst low-income households as a response to recent episodes of price instability.

Just as new downside risk attached to the rupee in the post-liberalization environment appears to have driven rural households away from storing value in cash, it may also be holding back the monetization of wages. Despite a large-scale shift from sharecropping to casual daily labour contracts in agriculture (Sayeed, 2008: 264), wages continue to be paid in grain, rather than in cash. ${ }^{8}$ The proposition explored further in Settle $(2016,2017)$ is that the shift out of cash is a risk management strategy that responds to instability in the rupee and in prices more generally. Explored in more detail in this article and specifically in relation to land, as discussed in the section below, is the role of liquidity in these practices. Here the shift out of cash can be interpreted as a hedge against rupee instability, which draws on diversification by spreading exposure across an array of alternative assets so as to not suffer heavy losses in the case of any one asset (such as the rupee) losing value.

Liquidity in these alternative assets is of paramount importance. Liquidity is crucial to the ability to rapidly reverse a position if market conditions suddenly change - particularly for assets that take the place in a portfolio that cash or bank deposits had previously held. The subsistence nature of wheat and cattle support their liquidity because of the consistently strong demand in the market for these items. Although little-used commodities like coffee, or formal financial instruments like equities or derivatives, may be only available in select locations in main cities, wheat can be used as a means of exchange for grocery purchases in rural and urban areas (Balagamwala and Gazdar, 2014; Gazdar and Mallah, 2013) and cattle can be sold in any village at any point of maturity, either to someone who trades in cattle or to an 'end user'. As such, these goods are useful instruments for

teacher. These locations are geographically and culturally close to Waheed's field site near Sarghoda, Punjab.

${ }^{8}$ A well-known fact in Pakistan, this was confirmed by each of the rural interviewees and by Mushtaq Gaadi, Professor of Anthropology and expert on agriculture in the Indus basin, interviewed in Islamabad, 23 April 2014.

This article is protected by copyright. All rights reserved. 
managing risk where instability in both traditional money and the value of commodities across the economy imposes financial risk.

Other examples of active strategies that mitigate new risk in the rupee under volatile monetary conditions include shopkeepers' daily practices of transferring out of the rupee, into either inventory purchases or foreign exchange. ${ }^{9}$ Dealers and traders alike discussed new practices amongst traders, by which rupees are converted into foreign exchange cash for overnight holdings. It was reported that 'commission agents' now visit shops in the bazaar to collect currency for exchange at the end of the day. Money dealers in Hyderabad, Peshawar and Lahore described shortterm holdings as becoming popular beyond traders, amongst ordinary people. 'Twenty years ago, people just exchanged money according to their needs', one dealer in Lahore explained in reference to foreign cash required for travel, notably the Haaj. 'Now people from every faction of society convert rupees into foreign currency. Ordinary people see it as a viable option for profit as compared to the banking sector ${ }^{\prime 10}$ Traders report daily conversion of rupee profits into new inventory. Rather than accumulating rupees for less frequent bulk purchases at a lower price, traders across the field sites reported daily purchases of storable commodities like edible oil and wheat. Similarly, a large agricultural landowner in Sindh reported that he himself, like other landowners in his area, had built new warehousing facilities on his land. Not only was he storing more of the commodities produced on his land but he was, like others, entering the market to purchase other storable commodities to hold and sell. ${ }^{11}$ This proposition appears plausible given reports of increased storage of agricultural commodities in the period after 2008 but is difficult to

${ }^{9}$ All 15 traders interviewed reported utilizing at least one of the strategies discussed in this section.

${ }^{10}$ This interview was undertaken with staff at a large money shop in a major money bazaar in Lahore, in Urdu with a local translator, on 19 April 2014. It is noted that the comment about foreign currency replacing bank accounts was not made in response to any questions about bank accounts, but was given in response to questions about who the dealer's customers are and why they change in and out of the rupee.

${ }^{11}$ Interview undertaken near Mirpurkhas with a medium-large agricultural landowner, in English, on 5 May 2014.

This article is protected by copyright. All rights reserved. 
confirm given data limitations and taboos around hoarding. ${ }^{12}$

These strategies can be understood to reflect a preference to keep highly liquid assets while limiting exposure to the rupee. Be it the grocer's choice to make wheat purchases every day or two rather than save up rupee profits for less frequent bulk purchases, the market opening for the 'commission agent' in the dollar trade, the landowners' new warehousing capacity, or the ubiquitous rural preference for cattle as an alternative to cash savings and wheat as wage denomination and payment, alternative liquid assets are being enhanced in portfolios where rupee holdings are being limited. These strategies identified in field interviews are thereby interpreted as acting to effectively hedge rupee risk by shifting value into a series of instruments that offer a similar profile to money attributes, but with less price risk than rupees carry. That is, the alternative instruments used in these strategies are extremely liquid, like money itself, but carry less risk of collapsing value.

In addition to these strategies, field interviews revealed that a popular method for hedging rupee volatility is through the market for vacant lots of land, known locally as 'plots'. The plot market was found to be thriving not only on the fringes of major cities, but also in a small, remote town. Notably, field interviews in Zhob, Balochistan, found an extremely active plot market. The huge inflows into the plot market in Zhob are particularly striking because Zhob is a remote district centre of some 25,000 people, where development indicators are among the worst in the country: around 60 per cent of the population is illiterate, over one-third of households have no access to sanitation facilities and infant mortality is far higher than in war-torn Afghanistan. ${ }^{13}$ Here, according to an interview with a local plot dealer, the booming plot market caters to families of expatriate labourers, as well as small shopkeepers and more typical customers such as the wealthier, salaried classes. ${ }^{14}$ The dealer explained that payments are often in cash. As advertised plot listings show, land

${ }^{12}$ Evidence of increasing capacity for food commodity storage amongst large landowners is found in Aazim (2014), A.S. Khan (2014) and Z.A. Khan (2008). The moral taboo of commodity hoarding is apparent in Z.A. Khan (2008) and discussed in depth in fieldwork by A.S. Khan (2014).

${ }^{13}$ These statistics pertain to Zhob District (Government of Balochistan and UNICEF, 2011).

${ }^{14}$ This interview was undertaken in Zhob, in Pashto, on 8 May 2014. Due to the sensitive security and cultural circumstances, the author was unable to be in the room during the interview. The

This article is protected by copyright. All rights reserved. 
sizes are commonly only $125 \mathrm{~m}^{2}$ (or 5 marla, a fraction of an acre) but can be as small as $25 \mathrm{~m}^{2}$ (1 marla - smaller than a double garage). Plots on the fringes of Pakistan's four major cities start at around US\$1,200, but small plots in more remote cities can cost as little as a few hundred dollars. ${ }^{15}$

The next section explores how informality enhances liquidity in plots and shows how informality has arisen at the same time as monetary volatility set in. It argues that increased informality in the plot market has effectively created new short-term assets that perform better for short-term storage of transactional balances than bank deposits or cash under the conditions of monetary volatility that are characteristic of the post-liberalization years. This proposition is developed out of information gathered in fieldwork undertaken primarily in 2016 , which included indepth interviews with five plot dealers, one developer, and a planner and draftsman, as well as five customers in the market. These interviews pertained to land markets in rural, urban and remote areas in Sindh, Punjab, Islamabad Capital Territory, Khyber Pakhtoonwa and Balochistan. As noted in the introduction, the land in question is not that of informal settlements, but formally recognized plots in development schemes around the country, which are transacted informally between market participants.

\section{Liquidity and Informality in Pakistan's 'Plot' Market}

The preference for liquidity in new and active strategies to limit rupee exposure found in the field would, in ordinary circumstances, be the key condition that would make the land market a poor substitute for money holdings. While in most of the world real estate is an important store-of-value asset, it is usually held for the long term, rather than as an asset that can rival money as a highly

interview was therefore undertaken by an experienced local researcher on behalf of the author during the field visit to Zhob.

${ }^{15}$ See http://www.zameen.com, where plots are listed for sale for further examples of plot prices.

This article is protected by copyright. All rights reserved. 
liquid short-term store-of-value and thus repository of transactional balances. Time-consuming documentation procedures that register land ownership with the state and the often large tax liabilities attached to land sales, make land slow and expensive to transact and thereby relatively illiquid.

In Pakistan, documentation for the transfer of land takes some three or four weeks to complete, which is a period considered reasonable by international norms. This process includes the registration of land ownership with a number of official offices and the issue of ownership documentation. ${ }^{16}$ The World Bank identifies a 'well-functioning' property market as one in which the purchase and transfer of land requires a period of less than 30 days to complete (Dowall and Ellis, 2009), suggesting that Pakistan's land market is 'well-functioning'. Field interviews with market participants confirmed that the plot market offers a valuable asset class as a market for short-term store-of-value assets with exceptional liquidity. These market actors consistently reported a growing trend in plot market investment since 2001. Although the plot market had long served as a market for long-term investment, in large part fuelled by remittances, in 2001 the market got a significant boost when large amounts of expatriate capital were returned to Pakistan in the wake of the September 2001 terror attacks in New York. ${ }^{17}$ All of the interviewees professionally engaged with the plot market ${ }^{18}$ reported that since around 2009, the market had become increasingly characterized by extremely short-term holdings - that is, holdings of only hours, days or weeks, as

${ }^{16}$ In field interviews, this process was described in detail by plot dealers and the period of time required confirmed by key market participants. For an accessible summary of the process, see Wahid (2015).

${ }^{17}$ Reverse capital flight from the US and UAE, where scrutiny of funds was undertaken in an effort to limit 'terror funding', was particularly significant (Zaidi, 2015: 530).

${ }^{18}$ Those engaged professionally with the plot market include two plot dealers from Islamabad, both interviewed in English in Islamabad on 13 May 2016; a plot dealer in Rawalpindi, interviewed in English on 14 May 2016; a plot dealer interviewed in Charsadda in Pashto, with a local translator, on 14 May 2016; a plot dealer interviewed in Zhob in Pashto, by an experienced local researcher, on 8 May 2014; a property developer, interviewed in English in Islamabad on 13 May 2016; and a planner and draftsperson, interviewed in Peshawar in Pashto, with a local translator, on 15 May 2016.

This article is protected by copyright. All rights reserved. 
well as holdings for a month or two. When asked how long his shortest plot holding was, one participant in the market, a bazaar-based auto-parts trader in Peshawar, answered 'half an hour'. ${ }^{19}$

As explained consistently by those professionally engaged with the plot market, the extreme liquidity implied by such short holdings is facilitated by informality. A buyer who wishes to hold a plot for a short period purchases the land by signing a so-called 'agreement to sell' document with the former owner and making full payment. In most cases, this is facilitated by a dealer who works on a 1 per cent commission. In any case, further documents that formalize the transfer in the eyes of the state are not completed. ${ }^{20}$ Only when the new owner (or more often the new owner's dealer) finds another buyer to sell the plot on to is the full documentation completed - but this documentation is completed without the short-term owner's name appearing on the documents.

Thus although payment is made and ownership is understood amongst those involved to have transferred from the person selling the plot to the buyer of the plot - and to have transferred on, some hours, days or weeks later, to a second buyer of the plot - the official paperwork only shows a transfer between the original seller and the second buyer. That is, the short-term buyer pays for a plot through the informal market without receiving the title. Not uncommonly, there can be a whole chain of people who buy and sell the same plot within short periods of time and within the terms of informality. Regardless of the land having passed through the hands of a series of shortterm owners, the land title will only show one transfer: between the original owner and the final buyer. By avoiding documentation, the processing period of official documents can thus be circumvented and a plot sold on whenever a buyer becomes available. That is, settlement becomes instant, rather than dependent on the period required for documents to be authorized by the state. By endowing plots with the attribute of potential rapid liquidation, informality in the plot market allows the plot market to cater to the kinds of short-term holdings for which people would otherwise use bank accounts and cash.

${ }^{19}$ Interview with an auto-parts dealer in Peshawar, in Pashto with a local translator, 15 May 2016. ${ }^{20}$ The exact documentation required differs between locations and types of land. However, in each case, what is excluded in an informal transaction is documentation that grants state authorization of the transfer (the fard). See Wahid (2015) for an accessible description of the relevant documents.

This article is protected by copyright. All rights reserved. 
Significantly, informality in the plot market appears to have arisen shortly after the rupee entered a period of sustained volatility in 2008 , at which point the capacity of the rupee to function as a short-term store-of-value became mired by downside risk. This timing further implicates informal plot holdings as a substitute for the rupee for short-term transactional balances. Between dealers, customers and other market participants, the recent emergence of short-term holdings was corroborated. From the consistency of these accounts, it appears that short-term holdings were introduced to the market only in $\mathbf{2 0 0 9}$ or thereabouts and have become a standard transaction in the years since then. The recent expansion of the plot market (and the greater liquidity that market expansion facilitates) is reflected in interview data, in which most market participants are relatively new entrants to the market. Of 12 market participants interviewed, seven had entered the market only since 2008 , including three of the five dealers interviewed. It was unclear with regard to two further participants when they had entered the market. Six had undertaken short-term informal holdings while the remaining six did not clarify their own personal use of the informal market for plots, but all were aware of informal plot transactions. ${ }^{21}$ No interviewees reported being involved with short-term informal transactions before 2008 , the point at which instability in the rupee became particularly severe. Indeed, the liquidity in the market that is required for short-term plot transactions may not have existed in the early 2000 s and, according to accounts offered by interviewees, certainly was not there in the 1990 s.

Further evidence of the transformation of the plot market into a market that caters for short-term holdings of transactional balances through informal transactions is drawn from across the interview data. In an agricultural area in Sindh, one market participant who had entered the market for the first time around 2010 and was, on the day of the interview, trying to liquidate a plot he had informally purchased 20 days earlier, described the workings of the plot market in his area. ${ }^{22}$ He explained that the price cycle for plots correspond to the peaks and troughs of the agricultural cycle. Hence when profits are realized after the harvest, plot prices boom as those in the agricultural sector place their earnings in plot purchases. In periods when costs are high but profits are yet to be

${ }^{21}$ Although these were detailed, semi-structured interviews, in some cases the sensitive nature of the questions precluded clarity around certain aspects of the interviewees' practices.

${ }^{22}$ This interview was undertaken outside Mirpurkhas, in English, on 3 May 2014.

This article is protected by copyright. All rights reserved. 
realized in the agricultural cycle, plot prices are at their lowest because liquidity has been withdrawn from the plot market to pay for spending associated with cultivation. Another participant, who designs housing schemes around Peshawar, explained that there has been a trend towards smaller plots in recent years that cater better to investor interests. ${ }^{23}$ He was able to show development plans that included large numbers of small plots which were set on the perimeter of the development. Larger plots, that would likely be sold to 'end users' and thus be built on relatively quickly, were spatially separated from smaller plots of $125-250 \mathrm{~m}^{2}$ that were designed to cater to investors and thus likely to remain empty for a longer period.

With greater numbers of small, cheaper plots on the market, plot holdings have become accessible to a broader clientele. This was implied by the plot dealer in Zhob, who at the time of the interview received a large cash payment wrapped in a ladies' scarf. ${ }^{24}$ The dealer described his clientele as including the families of expatriate labourers in the Gulf, many of whom are illiterate. Given that plot prices in smaller cities can be just a few hundred dollars, ${ }^{25}$ the broadening of clientele in the plot market certainly seems plausible. Indeed, for a remittance-receiving household seeking to store value for an intermittent period (for example, until school fees are due), the informal plot market would be ideal. While depositing in banks requires considerable documentation ${ }^{26}$ and a great deal of price risk, an informal position in the plot market, in which a plot is held for a short period without proper documentation, can be acquired rapidly and liquidated with little notice, free of the inconvenience of documentation and with little downside risk on the sum invested.

${ }^{23}$ This interview was undertaken in Peshawar, in Pashto, with a local researcher on 15 May 2016.

${ }^{24}$ This interview was undertaken in Zhob, in Pashto, on 8 May 2014.

${ }^{25}$ See http://www.zameen.com for current listings of plots for sale.

${ }^{26}$ The SBP has focused on reducing documentation related to both opening bank accounts and depositing in bank accounts, as part of its efforts to make bank deposits attractive to ordinary people. However, the SBP is also beholden to its commitments to curb 'terror funding' through strict 'know your customer' rules, which imposes its own burden of documentation.

This article is protected by copyright. All rights reserved. 
A drop-off in deposits in the banking sector appears to support the proposition that informal plot holdings have come to compete with bank deposits as store-of-value instruments that offer transactional access to savings. As discussed in greater detail in Settle (2017), the growth of the plot market in the years after 2008 coincides with a drop in the deposit base that, despite rigorous efforts on the part of the SBP, has still not recovered. Indeed two respondents explicitly stated that their plot holdings replaced the holdings that they had kept in bank accounts prior to the spike in inflation in $2008 .{ }^{27}$ The consistency of the research findings that the informal plot market was established in the same period that sustained rupee instability set in, implies a monetary role for plots where the rupee has been undermined by instability. By this reading, liquidity is a key feature of informality that attracts customers into the market.

Notwithstanding the benefit of liquidity, tax avoidance is also recognized as a potentially important factor in the appeal to potential customers of the informal plot market. Yet the peculiarities of the tax regime in Pakistan suggest that the gain from tax avoidance is far below global norms. At issue here is the massive undervaluation of land within official documentation processes, which reduces the tax burden to just a fraction of that set out by the tax code. The taxable value of land as stated in official documentation is linked to an official rate, known as the 'Deputy Commissioner' or DC rate. The DC rate allocates a reference value depending on size and location of the land, from which applicable fees and taxes are calculated. Corroborating estimations of the $D C$ rate made by those interviewed in the field, a survey of $D C$ rates in a recent newspaper article reports official rates to be 10-20 per cent of the market price (Abbasi, 2015). Hence an ostensible tax rate of 8 per cent of the value of land transacted becomes a payment of only some 0.8-1.6 per cent of the price paid for the property. ${ }^{28}$ As such, the tax benefits of trading land in the informal plot market are relatively modest. In any case, given that informal plot transactions pertain only to short-term holdings, the informal plot market offers only a short-term location to park money on a tax-free basis.

${ }^{27}$ These were the developer, interviewed in Islamabad, in English, on 13 May 2016, and the agricultural landholder interviewed near Mirpurkhas, in English, on 3 May 2014.

${ }^{28}$ See Wahid (2015) for a breakdown of taxes required.

This article is protected by copyright. All rights reserved. 
This article proposes that a salient driver of the dramatic growth of the plot market is demand for highly liquid assets in an environment in which the rupee has become extremely risky. Although the plot market itself is certainly not free of risk, ${ }^{29}$ its risk is very different to risk attached to the rupee. The risk attached to a short-term plot holding is a small chance of a large depreciation. The plot may be undermined in the formal market, for example if the development in which the plot is located becomes mired in controversy and consequently loses value. ${ }^{30}$ Or the plot might be undermined within the informal market, for instance if the person who first sold the plot into the informal market refuses to sign it over to the final seller in the chain of informal participants, who sells it back into the formal market. These are relatively small risks of individual participants failing to honour their commitments. A short-term holding of rupees, such as in a bank account, carries a much greater risk - small but much more likely downside losses generated by inflation and exchange rate depreciation.

The demand for highly liquid assets cannot be satisfied in the formal land market even though it is a 'well-functioning market', as determined by the World Bank. Only by operating in informal markets can this liquidity demand be satisfied. Here the imperative of liquidity - the ability to quickly switch positions - channels exchange into informal markets. The analogy by which informality facilitates liquidity which effectively transforms land into a short-term financial instrument can potentially be taken a step further. Where dealers arrange for land to be informally transacted they may settle the transaction as a net figure separate from the 'principal'. That is, A sells to $B$ without transferring the title; and B sells to $C$, with the title settled between $A$ and $C$. But rather than $B$ paying $A$, and $C$ paying $B$, the change in value of the land can be netted out and distributed between the three actors at the time of C's settlement. In most cases, the value of the land will go up, so C's settlement will be distributed between $A$ and $B$, with $B$ capturing the net increase in value and A taking the 'principal'. But in some cases, the value of the land will drop. If the

${ }^{29}$ As well as being more volatile as a result of more traditional shifts in supply and demand, declining land values are more common in Pakistan where pricing patterns can be disrupted due to manipulation of the market, including criminal activity and fraud. See, for example, Sattar (2016). ${ }^{30}$ For example, if the developer's commitment to develop infrastructure suddenly loses credibility.

This article is protected by copyright. All rights reserved. 
value of the land drops, then C's settlement value is paid directly to A (as if the principal), on top of which $B$ must also make a payment to $A$ equal to the net change in value.

Where this kind of netting out of payments occurs, we are seeing not so much trade in land itself but trade in exposure to the market performance of land. Here the underlying asset is not actually changing hands, either in a legal sense or in physical terms. Rather, B is buying exposure to change in the value of a piece of land over a certain period of time. As these periods of time can stretch from hours to days and months, a yield curve can be discerned, not unlike an interest rate yield curve, expressing the different returns over different time periods. But it is not uniform across space or smooth over time. This scenario demonstrates a more complex liquidity that can be facilitated by informally transacting land. Here informality not only facilitates liquidity that allows land to act as a short-term store-of-value instrument that can take the place of a bank deposit. More than this, informality here facilitates a degree of liquidity so great as to allow trade in exposure to an asset's market performance, much like a derivative product trades price movements on an asset without there being a formal trade in the asset itself.

\section{THE INFORMAL MARKET LITERATURE}

The use of informal markets in hedging practices found in Pakistan supports the rejection by the informal economy literature of earlier assumptions that informal markets are a pre-cursor to formal markets, destined to disappear with the spread of modern formal sectors. However, the assumption of informality as a transitory phenomenon is not rejected here for the same reasons as those usually identified in the informal economy literature. At issue here is voluntary 'exit' (Perry et al., 2007), but exit rooted specifically in monetary conditions: that is, a driver for informality that is embedded in regimes of liberalization and globalization and reflects 'well-functioning' but inflexible regulatory processes that cannot cater to new demands for financial liquidity. New hedging strategies in Pakistan thus tend to involve informal markets, but are neither an expression of exclusion from

This article is protected by copyright. All rights reserved. 
formal markets by marginalized actors (Coletto, 2010; Meagher and Lindell, 2013) nor a return to traditional social ties of solidarity and obligation (Hillenkamp et al., 2013).

Moreover, although the informal plot market does depend heavily on trust within social networks, the importance of trust between buyers and sellers in formal land transactions detracts from the distinction of social relations in informal transactions. That is, land titling is risky in any case in Pakistan (Dowall and Ellis, 2009; FIAS, 2005: 7), not least because within the legal framework the state does not guarantee title or the accuracy of the land records that it maintains (Soofi, 2015). ${ }^{31}$ It is not uncommon for fingerprints to be exchanged between buyer and seller, unmediated by the state, in order to enhance trust and credibility of documentation for formal plots. ${ }^{32}$ In this context, informal land transactions are less distinguished from their formal counterparts by the role of social networks in their transaction (which are also important in formal transactions); rather, the distinction of informal land markets lies in the liquidity that they facilitate.

The liquidity explored in this article contrasts to the concern for liquidity in some parts of the established literature. In the legalist perspective taken by de Soto and others, for example, formal documentation turns land from a 'dead' asset to a 'liquid' asset insofar as it can be more easily brought and sold, used as collateral and otherwise leveraged in a regime of legal protection of formal property rights (de Soto, 2000). In this view, land assets that are embedded in a regime of weak property rights are 'dormant' or 'underutilized' and thus must be subjected to policy targeted at 'unlock[ing] ... the latent value of property' (Mooya and Cloete, 2007: 147). Yet this is a different sense of liquidity. Distinct to liquidity that facilitates collateralization, the demand for liquidity identified in this article is one of immediate liquidity. Here liquidity is satisfied because plots can be rapidly liquidated, even if they can't act as collateral for mortgage finance. Plots can be transacted temporarily in the informal market so as to be utilized as reliable short-term assets because plots can move easily between formal and informal markets. We have already seen that, although beset

${ }^{31}$ Government documentation identifies who is responsible for paying taxes on land, rather than who actually owns the land. The World Bank suggests that some 40 per cent of all court disputes pertain to land (FIAS, 2005: 9).

${ }^{32}$ Fingerprinting was mentioned by the developer interviewed in Islamabad on 13 May 2016, and by the auto-parts dealer interviewed in Peshawar on 15 May 2016.

This article is protected by copyright. All rights reserved. 
by many of the kinds of problems that remain a concern to legalists, ${ }^{33}$ Pakistan's land market is regarded as 'well-functioning' in terms of the speed with which a transaction can be completed. The World Bank describes the regulatory framework for land registration and transfer as 'sound' (FIAS, 2005: 7). Yet the formal land market cannot satisfy the liquidity imperative that is being demanded. In these circumstances, immediate liquidity is satisfied only by informality.

Practices identified in Pakistan thus suggest a driver of informality that does not properly fit in the literature's established categories. These practices do not neatly reflect the lack of credibility in state institutions (Sindzingre, 2006), nor local cultural institutions substituting for formal institutions. This is not a case of 'reconfiguration of solidarity and protection mechanisms' (Saiag, 2013: 110) that rely on 'interdependencies within families, communities and professional, religious and other types of groups' (Hillenkamp et al., 2013: 6) nor does it demonstrate the salience of social networks in understanding informality (Meagher, 2010).

Where this analysis does agree with the literature is in the proposition that what we see in Pakistan is 'proliferation of artful transgressions that are the source of ... resilience' (Hillenkamp et al., 2013: 11). These are the same artful transgressions, however, as those made by hedge funds and investment banks in the financial sectors of advanced economies, where financial practices operating outside of regulated markets seek liquidity and diversification in the face of financial volatility. Indeed, in hedging practices found in Pakistan, it is the liquidity granted by the absence of documentation which suggests that informality is not a transitional phase for these markets but a necessity under the volatile monetary conditions familiar to open, developing economies. Here, it is argued, new monetary risks produce a new liquidity which is imperative as economic actors seek to protect themselves from bearing losses associated with volatile and declining prices in store-of-value assets. Far from the social embedding of informal exchange or exclusion from formal markets, the growing informal market activity identified in the research findings is more characteristic of the sophisticated financial hedging strategies evoked by financial globalization in the advanced

${ }^{33}$ For example, the patwari system, by which manual land records are maintained, is vulnerable to corruption, which has prompted projects seeking to digitalize land records (World Bank, 2006). Land markets in Pakistan, moreover, are very complex and the role of land in conflict in Karachi has attracted significant attention. See for example Gazdar and Mallah (2013) and Hasan et al. (2015).

This article is protected by copyright. All rights reserved. 
economies whereby liquidity, and thus informality, is crucial (Bryan and Rafferty, 2006). Not unlike strategies that operate amidst heavily deregulated markets in advanced economies, such as (undocumented) over-the-counter trading, synthetic positions, so called 'dark pools' and off-shore tax havens, these strategies secure highly liquid financial positions to offset risk exposure.

\section{CONCLUSION}

By drawing on fieldwork findings that identify new economic strategies and emphasize the role of informality in these strategies, this article has sought to demonstrate a potential link between contemporary global monetary conditions and strengthening preferences for informality. The analysis thereby posits that systemic conditions exist at the global level that support growing informality in local markets, not primarily in terms of exclusion or social networks, but through a growing imperative for liquidity.

The context against which these observations are drawn is distinctly monetary: with floating values oscillating sharply, the dominance of national currency as means of exchange, store-of-value and unit of measure is weakened. Access to other types of money both in domestic and foreign markets undermines the national currency, which itself increasingly looks like any other fluctuating and risky asset. Here money itself has become fluid - subject to continuous and accelerated change, its boundaries blurred - as the monopoly of state-issued currency used as money is undermined and its stable yardstick measure subjected to constant flux.

Under flux in value, grey zones arise between 'real' and financial markets, as reliable storeof-value assets are sought out, creating new speculative markets out of what had been ordinary markets for 'real' goods. And where 'real' goods are used as money, it is their financial characteristics that are attractive. Here liquidity is pivotal: markets for stores-of-value must be liquid in order to meet demand for money-like objects. That is, if a position cannot be rapidly reversed, it cannot provide the money function demanded by the public. It is here that informal markets thrive.

This article is protected by copyright. All rights reserved. 
Volatility in value generates uncertainty, and under these conditions the reversibility provided by unregulated markets serves an important aspect of market demand.

This article has drawn parallels between the liquid financial trading associated with high technology and elaborate mathematics in advanced economies, and new strategies of financial management undertaken by ordinary people in a low-income economy, in order to posit a new perspective on systemic change feeding preferences for informal market activity. Unlike the emphasis on social networks in the established literature, this perspective is oriented around the changing nature of economic flows and prices (Meagher, 2010: xi), focusing on the informal economy as a site of liquidity.

\section{REFERENCES}

Aazim, M. (2014) 'Poor Grain Storage Infrastructure', Dawn 6 October.

www.dawn.com/news/1136221/poor-grain-storage-infrastructure (accessed 4 November 2016).

Abbas, H., S. Beg and M.A. Choudhary (2015) 'Inflation Expectations and Economic Perceptions in a Developing Country Setting'. Karachi: State Bank of Pakistan.

Abbasi, A. (2015) 'Tax of Billions Evaded, Black Money Whitened Every Year', The News 23 November. www.thenews.com.pk/print/74907-tax-of-billions-evaded-black-money-whitened-everyyear (accessed 4 November 2016).

Agenor, P.R. and P.J. Montiel (2008) Development Macroeconomics. Princeton, NJ: Princeton University Press.

This article is protected by copyright. All rights reserved. 
Ahmed, W., M.A. Choudhary, S. Khan and G. Zoega (2013) 'Sticky Wages in a Developing Country: Lessons from Structured Interviews in Pakistan'. Discussion Papers in Economics 02/13. Guildford: University of Surrey.

Anand, R. and P. Cashin (2016) Taming Indian Inflation. Washington, DC: International Monetary Fund.

Balagamwala, M. and H. Gazdar (2014) 'Life in a Time of Food Price Volatility: Evidence from Two Communities in Pakistan'. IDS Working Paper No. 2014/449. Brighton: Institute of Development Studies.

Birch, E.L., S. Chattaraj and S.M. Wachter (2016) Slums: How Informal Real Estate Markets Work. Philadelphia, PA: University of Pennsylvania.

Black, F. and M. Scholes (1973) 'The Pricing of Options and Corporate Liabilities', Journal of Political Economy 81(3): 637-54.

Brana, S., M.L. Djigbenou and S. Prat (2012) ‘Global Excess Liquidity and Asset Prices in Emerging Countries: A PVAR Approach', Emerging Markets Review 13(3): 256-67.

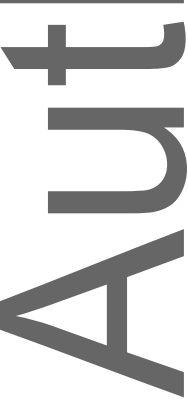

Bryan, D. and M. Rafferty (2006) Capitalism with Derivatives: The Political Economy of Financial Derivatives, Capital and Class. New York: Palgrave.

This article is protected by copyright. All rights reserved. 
Choudhary, M.A. and F. Pasha (2013) 'The RBC View of Pakistan: A Declaration of Stylized Facts and Essential Models'. Discussion Papers in Economics No. 04/13. Guildford: University of Surrey.

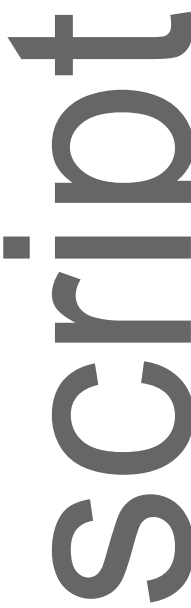

Coletto, D. (2010) The Informal Economy and Employment in Brazil: Latin America, Modernization, and Social Changes. New York: Palgrave Macmillan.

Dowall, D.E. and P.D. Ellis (2009) 'Urban Land and Housing Markets in the Punjab, Pakistan', Urban Studies 46(11): 2277-300.

Eichengreen, B. (2008) Globalizing Capital: A History of the International Monetary System. Princeton, NJ: Princeton University Press.

FIAS (2005) 'Improving the Performance of the Housing, Tourism and Retail Sectors in Pakistan'.

Washington, DC: Foreign Investment Advisory Service/World Bank/IFC.

Gazdar, H. and H.B. Mallah (2013) 'Inflation and Food Security in Pakistan: Impact and Coping Strategies', IDS Bulletin 44(3): 31-37.

Government of Balochistan and UNICEF (2011) 'Zhob: District Development Profile'. Quetta:

Planning and Development Department, Government of Balochistan.

This article is protected by copyright. All rights reserved. 
Hamid, N., I. Nabi and N. Anjum (1990) Trade, Exchange Rate, and Agricultural Pricing Policies. Washington, DC: World Bank.

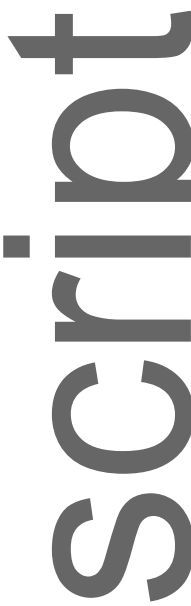

Hanif, M.N., J. Iqbal and I.N. Khan (2016) ‘Global Commodity Prices and Inflation in a Small Open Economy'. SBP Working Paper No. 76. Karachi: State Bank of Pakistan.

Hasan, A., N. Ahmed, M. Raza, S.U. Ahmed, M.B. Sarwar and A. Sadiq-Polack (2015) Karachi: The Land Issue. Karachi: Oxford University Press.

Hasan, M.A., A.H. Khan, H.A. Pasha, M.A. Rasheed and A.M. Hussain (1995) 'What Explains the Current High Rate of Inflation in Pakistan', The Pakistan Development Review 34(4): 927-43.

Helleiner, E. (1994) States and the Reemergence of Global Finance: From Bretton Woods to the 1990s. Ithaca, NY: Cornell University Press.

Hillenkamp, I., F. Lapeyre and A. Lemaitre (2013) 'Introduction: Informal Economy, Vulnerabilities, and Popular Security-enhancing Practices', in I. Hillenkamp, F. Lapeyre and A. Lemaitre (eds) Securing Livelihoods: Informal Economy Practices and Institutions, pp. 1-25. Oxford: Oxford University Press.

Hussein, S., A. Saeed and A. Hassan (2011) 'The Financial Accelerator: An Emerging Market Story'. SBP Working Paper No. 41. Karachi: The State Bank of Pakistan.

Ito, H. and M. Chinn (2017) 'Notes on the Chinn-Ito Financial Openness Index 2015 Update'. http://web.pdx.edu/ ito/Readme_kaopen2015.pdf

This article is protected by copyright. All rights reserved. 
Keynes, J.M. (1936) The General Theory of Employment, Interest and Money. New York: Harcourt Brace and Company.

Khan, A.S. (2014) 'Pakistan's Food Security from Wheat Value Chain Perspective'. PhD dissertation, University of Auckland.

Khan, M. (2015) 'The PKR and Price-setting Behaviour'. Staff Notes 02/15. Karachi: The State Bank of Pakistan.

Khan, M.A. and A. Ahmed (2014) 'Revisiting the Macroeconomic Effects of Oil and Food Price Shocks to Pakistan Economy: A Structural Vector Autoregressive (SVAR) Analysis', OPEC Energy Review 38(2): 184-215.

Khan, Z.A. (2008) 'Labour Leaders Vent their Rage on Govt', Dawn 11 May. www.dawn.com/news/302171/labour-leaders-vent-their-rage-on-govt (accessed 4 November 2016).

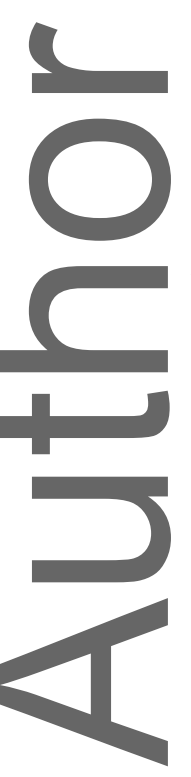

Kuran, T. (1986) 'The Economic System in Contemporary Islamic Thought: Interpretation and Assessment', International Journal of Middle East Studies 18(2): 135-64.

Lopez-Calix, J.R., T.G. Srinivas and M. Waheed (2011) 'What We Know about Growth Patterns in Pakistan'. World Bank Policy Paper Series on Pakistan No. PK05/12. Washington, DC: World Bank.

This article is protected by copyright. All rights reserved. 
Markowitz, H.M. (1959) Portfolio Selection: Efficient Diversification of Investments. New York: John Wiley and Sons.

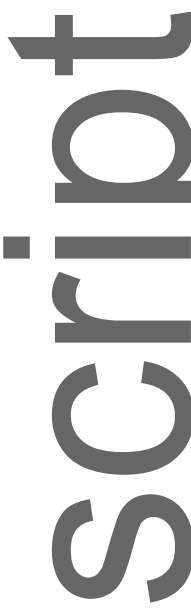

Meagher, K. (2005) 'Social Capital or Analytical Liability? Social Networks and African Informal Economies', Global Networks 5(3): 217-38.

Meagher, K. (2010) Identity Economics: Social Networks and the Informal Economy in Nigeria. Oxford: James Currey; Ibadan: HEBN.

Meagher, K. and I. Lindell (2013) 'ASR Forum. Engaging with African Informal Economies: Social Inclusion or Adverse Incorporation', African Studies Review 56(3): 57-76.

Meenai, S.A and J.A. Ansari (2004) Money and Banking in Pakistan (6 ${ }^{\text {th }}$ edn). Karachi: Oxford University Press.

Mooya, M.M., and C.E. Cloete (2007) 'Informal Urban Property Markets and Poverty Alleviation: A Conceptual Framework', Urban Studies 44(1): 147-65.

Perry, G.E. et al. (2007) Informality: Exit and Exclusion. Washington, DC: World Bank.

This article is protected by copyright. All rights reserved. 
Players Capital Group (2014) 'Understanding Liquidity and What It Means to You'. Blog post. http://www.playerscapital.net/blog-posts/hows-your-liquidity/ (accessed 4 November 2016).

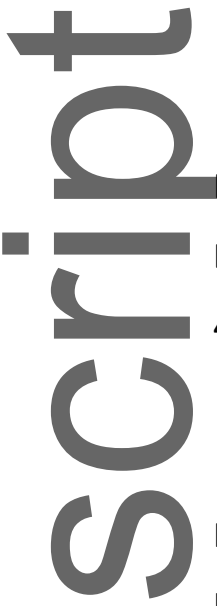

Portes, A. (1994) 'Paradoxes of the Informal Economy: The Social Basis of Unregulated

Entrepreneurship', in J.S. Neil and R. Swedberg (eds) The Handbook of Economic Sociology, pp. 42649. Princeton, NJ: Princeton University Press.

Rashid, A. and F. Husain (2010) 'Capital Inflows, Inflation and Exchange Rate Volatility: An Investigation for Linear and Nonlinear Causal Linkages'. PIDE Working Papers No 2010: 63. Islamabad: Pakistan Institute of Development Economics.

Saiag, H. (2013) 'The Dynamics of Solidarity and Protection in the Suburbs of Rosario, Argentina', in I. Hillenkamp, F. Lapeyre and A. Lemaitre (eds) Securing Livelihoods: Informal Economy Practices and Institutions, pp. 99-114. Oxford: Oxford University Press.

Sattar, B. (2016) 'Land Scams and Half-truths', The News 16 January.

www.thenews.com.pk/print/90657-Land-scams-and-half-truths (accessed 4 November 2016).

Sayeed, A. (2008) 'Pakistan', in D. Lee, A. Leong, R. Ofreneo and A. Sukumaran (eds) Rights for Twothirds of Asia: Asian Labour Law Review, pp. 259-70. Hong Kong: Asia Monitor Resource Centre.

SBP (2008) 'Annual Report 2007-2008'. Karachi: State Bank of Pakistan.

SBP (2009) 'Annual Report 2008-2009'. Karachi: State Bank of Pakistan.

This article is protected by copyright. All rights reserved. 
Settle, A.C. (2016) 'Locating Financialization in a Less-developed Economy: Micro Responses to Liberalization and Volatility in Pakistan', Competition and Change 20(2): 106-21.

Shatkin, G. (2004) 'Planning to Forget: Informal Settlements as "Forgotten Places” in Globalising Manila', Urban Studies 41(12): 2469-84.

Sindzingre, A. (2006) 'The Relevance of the Concepts of Formality and Informality: A Theoretical Appraisal', in B. Guha-Khasnobis, R. Khambur and E. Ostrom (eds) Finding the Formal and Informal Economy: Concepts and Policies, pp. 58-74. Oxford: Oxford University Press.

Soofi, B.B. (2015) 'Insecure Land Title’, Dawn 5 April. www.dawn.com/news/1173963 (accessed 4 November).

de Soto, H. (2000) The Mystery of Capital: Why Capitalism Triumphs in the West and Fails Everywhere Else. New York: Basic Books.

This article is protected by copyright. All rights reserved. 
ul Haque, I. (2010) 'Pakistan: Causes and Management of the 2008 Economic Crisis'. Third World Network Global Economy Series No. 22. Penang: Third World Network.

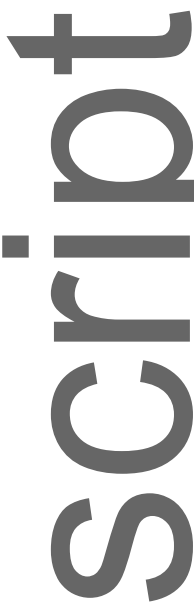

Il Haque I. (2011) 'The Capital Account and Pakistani Rupee Convertibility: Macroeconomic Policy Challenges', The Lahore Journal of Economics 16: 95-121.

Waheed, S. (1996) 'Household Savings in Rural Pakistan: Empirical and Conceptual Issues'. PhD dissertation, Georg-August Universitaet, Goettingen.

Wahid, P. (2015) 'Legal Procedure Pertaining to Sale of Land, Residential and Commercial Property in Pakistan (Excluding Federal Territory)'. Islamabad: Josh and Mak International.

https://joshandmakinternational.com/legal-procedure-pertaining-to-selling-property-in-pakistanexcluding-federal-territory/.

Walsh, J.P. (2011) 'Reconsidering the Role of Food Prices in Inflation'. IMF Working Paper No. 11/17. Washington, DC: International Monetary Fund.

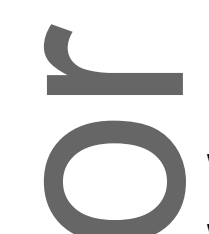

World Bank (2006) 'Punjab Land Records Management and Information Systems Project'.

Washington, DC: World Bank.

www.documents.worldbank.org/curated/en/280181468289824118/pdf/36450.pdf (accessed

November 4 2016)

Zaidi, A. (2005) Issues in Pakistan's Economy (2 ${ }^{\text {nd }}$ edn). Karachi: Oxford University Press.

This article is protected by copyright. All rights reserved. 
Zaidi, A. (2015) Issues in Pakistan's Economy: A Political Economy Perspective ( $3^{\text {rd }}$ edn). Karachi: Oxford University Press.

Antonia C. Settle (aset7246@uni.sydney.edu.au) is a PhD student in the Department of Political Economy at the University of Sydney, Australia. Her research interests include financial and monetary change, households and risk.
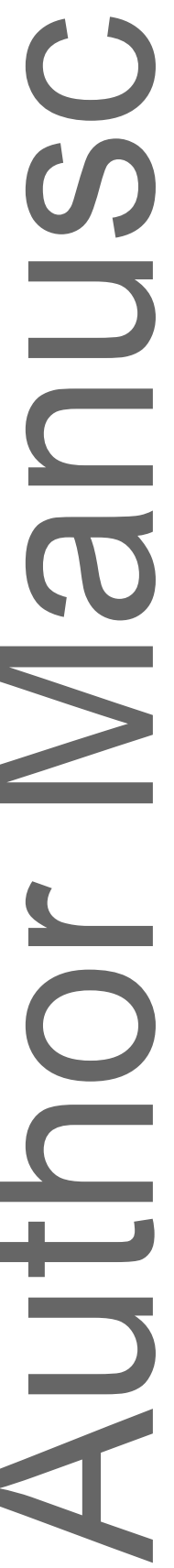

This article is protected by copyright. All rights reserved. 


\section{University Library}

\section{- M M N E R VA A gateway to Melbourne's research publications}

Minerva Access is the Institutional Repository of The University of Melbourne

Author/s:

Settle, AC

Title:

The Informal Economy as a Site of Liquidity: Pakistan's Land Market

Date:

2018-09-01

Citation:

Settle, A. C. (2018). The Informal Economy as a Site of Liquidity: Pakistan's Land Market.

DEVELOPMENT AND CHANGE, 49 (5), pp.1291-1313. https://doi.org/10.1111/dech.12425.

Persistent Link:

http://hdl.handle.net/11343/285070 